\title{
The Impact of Parental Myopia on Myopia in University Students: A Cross-Sectional Study from Shanghai, China
}

\section{Weiran Li}

Shanghai Jiao Tong University School of Medicine

\section{Pengcheng Xun}

Indiana University Bloomington

Chang Cui

Shanghai Jiao Tong University School of Medicine

Jibo Zhou ( $\square$ zhoujibo1000@aliyun.com )

Shanghai Ninth People's Hospital, Shanghai Jiao Tong University School of Medicine https://orcid.org/0000-0003-0684-0302

\section{Research article}

Keywords: refractive error, parental myopia, prevalence, risk factors, university students

Posted Date: June 4th, 2020

DOI: https://doi.org/10.21203/rs.3.rs-29156/v1

License: (9) This work is licensed under a Creative Commons Attribution 4.0 International License. Read Full License 


\section{Abstract}

Background: To evaluate the effect of parental myopia on Chinese university students with a high prevalence of myopia in Shanghai.

Methods: A cross-sectional study of university students in Shanghai, China. All participants responded to a detailed questionnaire, including questions about age, ethnicity and family history. They underwent a standardized ophthalmological examination, including visual acuity, a slit lamp examination and noncycloplegic auto-refraction. Generalized linear model was used to identify risk factors for myopia.

Results: Of the 11,977 total subjects, $91.55 \%$ were myopic (spherical equivalent refraction [SER] $\leq-0.75$ D), $20.18 \%$ were highly myopic (SER $\leq-6.0 \mathrm{D})$ and only $6.94 \%$ were emmetropic ( $-0.75 \mathrm{D} \otimes S E R \leq 0.75 \mathrm{D})$. The mean age of the myopic participants $(19.7 \pm 2.4)$ was higher than that of the emmetropic participants $(19.3 \pm 1.9, p<0.001) .10391(91.8 \%)$ of Han students were myopic, which exhibited greater myopia than minority students $(91.5 \%, \mathrm{p}<0.001)$. Among the students from families with two myopic parents, $97.9 \%$ had myopia. Only $93.7 \%$ of students had myopia where only one parent was myopic, and among the students without myopic parents, $90.7 \%$ had myopia $(p<0.001)$. Female students whose parents were myopic (8.0\%) were more likely to have myopia than male students whose parents were myopic $(7.5 \%)(p$ $<0.001$ ). Students with two myopic parents (mean difference: $-2.04,95 \% \mathrm{Cl}:-2.21,-1.86)$ were at a high risk of myopia compared with students with no myopic parents $(p<0.001)$.

Conclusions: This study showed that the refractive status of children in a population with a high prevalence of myopia was related to the status of parents. Increased severity of parental myopia led to a greater risk of myopia in their children.

\section{Background}

Myopia, one of the most prevalent refractive errors, has become a major public health issue worldwide [1-3]. There are approximately 1950 million people with myopia worldwide (28.3\% of the global population) [4]. However, the prevalence of myopia varies across the world. According to current surveys, the prevalence is higher in Asian countries such as China (73.1\%) [5], Korea (70.6\%) [6] and Singapore (79.3\%) [7] than in countries such as Norway (35.0\%) [8], the UK (26.9\%) [9], the United States (33.1\%) [10] and Australia (11.9\%) [11]. An increase in the myopia rate has resulted in an increase in the prevalence of high myopia. High myopia is associated with severe ocular issues, including myopic maculopathy, choroidal neovascularization, macular holes, myopic retinoschisis, retinal detachment and open-angle glaucoma [12-15]. Based on the growing prevalence of refractive errors and high myopia, it is increasingly important to find ways to reduce myopia rates among the younger generation in East and Southeast Asia [16].

Myopia is thought to have a multifactorial etiology, including intensive education [17], lifestyle [18-20], parental myopia [21, 22] and a lower serum 25-hydroxyvitamin D (25[OH]D) concentration [6]. The association between genetic factors and myopia has been extensively analyzed [23-28]. The myopia 
status of children is reported to be closely related to the status of their parents. Only two studies did not find an association between parental and juvenile myopia [29,30]. Our research focused mainly on the relationship between hereditary factors and myopia in a Shanghai university student population with a high prevalence of myopia.

\section{Methods}

\section{Participants}

This was a cross-sectional study of the characteristics of ocular biometry in university students in Shanghai, China [31]. The students were recruited from Donghua University (DHU), located in the Changning district of Shanghai, and Shanghai University of Medicine \& Health Sciences (SUMHS). Study participants were recruited using cluster sampling; all first-year undergraduates and first-year Master's degree students were selected. The fieldwork was carried out during September 2009 and October 2010. Each student's name, sex, and student ID number were registered at the student affairs office. Among the 12,711 subjects selected, 11,977 students participated in the study (response rate of $94.23 \%$ ). Students who had had corneal or scleral surgery or any other eye disease that would damage their visual acuity were excluded.

All participants received detailed information about the study before being enrolled. Informed consent was obtained according to the Declaration of Helsinki. The Shanghai JiaoTong University School of Medicine Ethics Review Board and the Ethics Committee of Shanghai Ninth People's Hospital approved the study.

\section{Questionnaire And Ophthalmic Examination}

Students were selected by an ophthalmologist to complete a questionnaire, which included questions about their date of birth, nationality, history of myopia, history of other eye diseases and family history of either myopia or hereditary diseases. In detail, the parents' refractive status was filled in by students with emmetropia, low myopia, moderate myopia and high myopia. Next, a second ophthalmologist performed a simple ocular examination using a slit lamp to exclude opacity of the optical media. Visual acuity was then measured as uncorrected visual acuity (UCVA) (Snellen charts) at a distance of $5 \mathrm{~m}$. An automatic refractometer (Auto Refractometer, AR-600; Nidek Ltd., Tokyo, Japan) was used to obtain a measurement of the refractive error without cycloplegia, and the average value of five repetitions was recorded. If the UCVA was $<1.0$, the corrected visual acuity was measured by subjective refraction.

\section{Statistical Analysis}

All data were entered into Epidata (version 3.1) and statistical analyses were performed using SPSS software (version 22.0; IBM Corp., Armonk, NY, USA). Spherical equivalent refraction (SER) was calculated as the spherical value of the refractive error plus half of the cylindrical value. All of the numerical data are 
given as the means \pm standard deviation (SD). Myopia was defined as an SER <-0.75 diopters (D), and these cases were further categorized into three subgroups based on the magnitude of the SER: low myopia $(-3.00 \mathrm{D} \leq \mathrm{SER}<-0.75 \mathrm{D})$, moderate myopia $(-6.0 \mathrm{D} \leq \mathrm{SER}<-3.0 \mathrm{D})$, and high myopia $(\mathrm{SER}<-6.0$ D). Emmetropia was taken as an SER score between $-0.75 \mathrm{D}$ and $+0.75 \mathrm{D}$; an SER value $>0.75 \mathrm{D}$ was regarded as hyperopia. Means were compared by independent $t$-tests. Chi-squared tests were used to analyze the enumeration data. Generalized linear model was used in multivariate analyses. All p-values were two-sided and were considered statistically significant at $p<0.05$.

\section{Results}

\section{Participants' characteristics}

Among the 12,711 selected subjects, the response rate was 11,977 (94.2\%), of which $4,191(35.0 \%)$ were male and 7,786 (65.0\%) were female. According to Fig. 1, only 54 students were hypermetropic, and the number of emmetropia was 777. 5218 Students who were moderate myopic counted most (43.6\%). There were 3511 and 2417 students with low myopia and high myopia, respectively. Table 1 showed that the mean age of the participants was $19.7 \pm 2.4$ years, and the mean age of the myopic participants was higher than that of the emmetropic participants $(p<0.001)$. Interestingly, when we divided the age of students into freshmen and postgraduate students, the difference between myopia and non-myopia students had no statistical significance. The 11,977 participants included 11,273 Han Chinese and 704 from other minorities. The Han Chinese students had higher rates of myopia than the minority students $(p<0.001)$. There was no difference in the prevalence rates of myopia according to birth season $(p=$ $0.100)$ and sex $(p=0.404)$. Among the participants with myopia, $2,270(20.7 \%)$ had a mother with myopia and 2,201 $(20.07 \%)$ had a father with myopia. Among the students from families with two myopic parents, $97.9 \%$ had myopia. Of the students with only one myopic parent, $93.7 \%$ had myopia, compared with $90.7 \%$ of the students without myopic parents $(p<0.001)$. These results indicated that parents with myopia tend to have children with myopia. 
Table 1

Characteristics of the 11,977 study participants ${ }^{a}$

\begin{tabular}{|c|c|c|c|c|}
\hline \multirow[t]{2}{*}{ Characteristics } & \multirow[t]{2}{*}{ Total } & \multicolumn{2}{|l|}{ Myopia } & \multirow[t]{2}{*}{ p-value } \\
\hline & & No & Yes & \\
\hline No. of participants & $11,977^{\mathrm{a}}$ & 1,012 & 10,965 & - \\
\hline Age, years & $19.7 \pm 2.4$ & $19.3 \pm 1.9$ & $19.7 \pm 2.4$ & $<0.001$ \\
\hline Freshmen & & $18.8 \pm 1.2$ & $18.9 \pm 2.7$ & 0.477 \\
\hline Postgraduate & & $22.4 \pm 3.8$ & $23.0 \pm 3.2$ & 0.116 \\
\hline \multicolumn{5}{|l|}{ Sex } \\
\hline Male & $4191(35.0)$ & $342(8.2)$ & 3849 (91.8) & \multirow[t]{2}{*}{0.404} \\
\hline Female & $7786(65.0)$ & $670(8.6)$ & $7116(91.4)$ & \\
\hline \multicolumn{5}{|l|}{ Ethnicity } \\
\hline Han & $11273(94.1)$ & $882(7.8)$ & 10391 (92.2) & \multirow[t]{2}{*}{$<0.001$} \\
\hline Minorities & $704(5.9)$ & $130(18.5)$ & $574(81.5)$ & \\
\hline \multicolumn{5}{|l|}{ Birth season } \\
\hline Spring & $2640(22.0)$ & $231(8.8)$ & 2409 (91.3) & \multirow[t]{4}{*}{0.100} \\
\hline Summer & 2908 (24.3) & $273(9.4)$ & $2635(90.6)$ & \\
\hline Fall & 3414 (28.5) & $294(8.0)$ & $3140(92.0)$ & \\
\hline Winter & 3015 (25.2) & $234(7.8)$ & 2781 (92.2) & \\
\hline Parental myopia status & 2384 (19.9) & $114(4.8)$ & $2270(95.2)$ & \multirow[t]{4}{*}{$<0.001$} \\
\hline Maternal myopia & $9593(80.1)$ & $898(9.4)$ & 8695 (90.6) & \\
\hline Yes & & & & \\
\hline No & & & & \\
\hline Paternal myopia & 2307 (19.3) & $106(4.6)$ & $2201(95.4)$ & \multirow[t]{3}{*}{$<0.001$} \\
\hline Yes & $9670(80.7)$ & $906(9.4)$ & $8764(90.6)$ & \\
\hline No & & & & \\
\hline Parental myopia status & & & & \\
\hline
\end{tabular}

a The data are means \pm SD or $\mathrm{n}$ (proportion, \%).

${ }^{\mathrm{b}} \mathrm{p}$-values were obtained using the $t$-test or chi-squared test, as appropriate. 


\begin{tabular}{|lllll|}
\hline Characteristics & Total & Myopia & & \multirow{2}{*}{ p-value $^{\mathbf{b}}$} \\
\cline { 3 - 4 } & & No & Yes & \\
\hline Neither & $8161(68.1)$ & $810(9.9)$ & $7351(90.1)$ & $<0.001$ \\
\hline Mother or father & $2941(24.6)$ & $184(6.3)$ & $2757(93.7)$ & \\
\cline { 1 - 4 } Both & $875(7.3)$ & $18(2.1)$ & $857(97.9)$ & \\
\hline a The data are means \pm SD or $n$ (proportion, \%). & & \\
\hline b p-values were obtained using the $t$-test or chi-squared test, as appropriate. \\
\hline
\end{tabular}

Characteristics of college students according to their parental myopia status

As shown in Table 2, 1,868 female students had only one myopic parent, accounting for $26.3 \%$ of the total number of females, and only 889 male students were myopic if they had one parent with myopia, accounting for only $23.1 \%$ of the total number of males. Similarly, among the students whose parents were myopic, the myopia rate in female students (8.0\%) was higher than that in males $(7.5 \%)$. Table 2 also shows that Han students whose parents were myopic were more likely to have myopia $(7.7 \%)$ than minority students with myopic parents $(7.5 \%)(p=0.013)$.

Table 2

Characteristics of the 11,977 students according to their parental myopia status

\begin{tabular}{|lllll|}
\hline $\begin{array}{l}\text { Parental myopia status } \\
\text { (mother, father) }\end{array}$ & $\begin{array}{l}\text { Myopia (male } \\
\text { students) }\end{array}$ & $\begin{array}{l}\text { Myopia (female } \\
\text { students) }\end{array}$ & Han & Minorities \\
\cline { 2 - 5 } & $\mathbf{n}$ (proportion) & $\mathbf{n}$ (proportion) & $\begin{array}{l}\text { n } \\
\text { (proportion) }\end{array}$ & $\begin{array}{l}\text { n } \\
\text { (proportion) }\end{array}$ \\
\hline$(-,-)$ & $2671(69.4)$ & $4680(65.8)$ & $6966(66.8)$ & $424(72.2)$ \\
\hline$(+,-)$ or $(-,+)$ & $889(23.1)$ & $1868(26.3)$ & $2658(25.5)$ & $119(20.3)$ \\
\hline$(+,+)$ & $289(7.5)$ & $568(8.0)$ & $799(7.7)$ & $44(7.5)$ \\
\hline p-value a & $<0.001$ & & 0.013 & \\
\hline a p-values were obtained using the Mann-Whitney test & & \\
\hline
\end{tabular}

The association between parental myopia status and the refractive error (diopters) among students (Tables 3-4,Figure 2-3) 
Table 3

Generalized linear model analysis of parental myopia status and the refractive error (Diopters) among 11,977 Chinese university students

\begin{tabular}{|c|c|c|c|c|c|c|}
\hline & & \multicolumn{4}{|c|}{ Parental myopia status ${ }^{a}$} & \multirow{2}{*}{$\begin{array}{l}\text { P for trend } \\
\text { d }\end{array}$} \\
\hline & & 0 & 1 & 2 & 3 & \\
\hline \multirow[t]{2}{*}{$\begin{array}{l}\text { Model } \\
1^{\mathrm{b}}\end{array}$} & Father & $\begin{array}{l}0 \\
\text { (Ref.) }\end{array}$ & $\begin{array}{l}-0.83(-1.01 \\
-0.66)^{e}\end{array}$ & $\begin{array}{l}-0.98(-1.14, \\
-0.81)\end{array}$ & $\begin{array}{l}-1.38(-1.64, \\
-1.13)\end{array}$ & $<0.001$ \\
\hline & Mother & $\begin{array}{l}0 \\
\text { (Ref.) }\end{array}$ & $\begin{array}{l}-0.79(-0.96 \\
-0.63)\end{array}$ & $\begin{array}{l}-1.00(-1.17, \\
-0.84)\end{array}$ & $\begin{array}{l}-1.77(-2.01, \\
-1.53)\end{array}$ & $<0.001$ \\
\hline \multirow[t]{2}{*}{$\begin{array}{l}\text { Model } \\
2^{c}\end{array}$} & Father & $\begin{array}{l}0 \\
\text { (Ref.) }\end{array}$ & $\begin{array}{l}-0.86(-1.03 \\
-0.68)\end{array}$ & $\begin{array}{l}-1.00(-1.16 \text {, } \\
-0.84)\end{array}$ & $\begin{array}{l}-1.41(-1.66, \\
-1.15)\end{array}$ & $<0.001$ \\
\hline & Mother & $\begin{array}{l}0 \\
\text { (Ref.) }\end{array}$ & $\begin{array}{l}-0.83(-1.00 \\
-0.66)\end{array}$ & $\begin{array}{l}-1.04(-1.20 \\
-0.87)\end{array}$ & $\begin{array}{l}-1.81(-2.05 \\
-1.57)\end{array}$ & $<0.001$ \\
\hline
\end{tabular}

a 0: Hypermetropia and emmetropia; 1: Low myopia; 2: Moderate myopia; 3: High myopia.

${ }^{\mathrm{b}}$ Model 1 was a crude model without adjustment.

${ }^{c}$ Model 2 was adjusted for age and ethnicity.

${ }^{d}$ Tests for a linear trend were performed by entering parental myopia status as a continuous variable for all of the models.

${ }^{\text {e }}$ Mean difference (95\% Wald confidence interval) was estimated using the model. 
Table 4

The association (mean difference $[95 \% \mathrm{Cl}]$ ) between the joint classification of parental myopia status and the refractive error (Diopters) among 11,977 college students

\begin{tabular}{|c|c|c|c|c|}
\hline & \multicolumn{3}{|c|}{ Parental myopia status (mother, father) a } & \multirow[t]{2}{*}{ p for trend ${ }^{d}$} \\
\hline & $(-,-)$ & $(+,-) /(-,+)$ & $(+,+)$ & \\
\hline Model $1^{\mathrm{b}}$ & 0 (Ref.) & $-1.03(-1.14,-0.93)^{e}$ & $-1.98(-2.15,-1.80)$ & $<0.001$ \\
\hline Model $2^{c}$ & 0 (Ref.) & $-1.06(-1.16,-0.96)$ & $-2.04(-2.21,-1.86)$ & $<0.001$ \\
\hline \multicolumn{5}{|c|}{ a -: Not myopic; +: Myopic. } \\
\hline \multicolumn{5}{|c|}{ b Model 1 was a crude model without adjustment. } \\
\hline \multicolumn{5}{|c|}{${ }^{\mathrm{c}}$ Model 2 was adjusted for age and ethnicity. } \\
\hline \multicolumn{5}{|c|}{$\begin{array}{l}\mathrm{d} \text { Tests for a linear trend were performed by entering parental myopia status as a continuous variabl } \\
\text { for all of the models. }\end{array}$} \\
\hline \multicolumn{5}{|c|}{ e Mean difference (95\% Wald confidence interval) was estimated using the model. } \\
\hline
\end{tabular}

To further analyze the influence of hereditary factors on the offspring according to the degree of myopia in their parents, the SER of students was used as the dependent parameter and age, sex, ethnicity and parental myopia status as the independent variables in the first step of a generalized linear model analysis. In the multivariate analysis, age and ethnicity were adjusted for, and the remaining parameters that were significantly associated with myopia in a stepwise fashion in the univariate analyses were included.

The results in Table 3 showed that students with fathers with high myopia had a SER of 1.41D less than students without a myopic father (mean difference: $-1.41,95 \% \mathrm{Cl}:-1.66,-1.15, \mathrm{p}<0.001$ ), and students with a mother with high myopia were more likely to be myopic compared with students without a myopic mother (mean difference: $-1.81,95 \% \mathrm{Cl}:-2.05,-1.57, \mathrm{p}<0.001$ ). It can be analyzed that the higher the degree of myopia of father, the lower the SER of the child. The same went for mother's results (Table 3 , Fig. 2). As shown in Table 4, students with two myopic parents were at a high risk of myopia (mean difference: $-2.04,95 \% \mathrm{Cl}:-2.21,-1.86, \mathrm{p}<0.001$ ) (Table 4, Fig. 3). Tables 3 and 4 both showed that the SER in college students was strongly related to the myopia status of their parents $(p<0.001)$.

\section{Discussion}

In this study, we found that the myopia status of children in a population with a high myopia prevalence was associated with the myopia status of their parents. Although four of five myopic students didn't have myopic parents, the influence of parents' myopia could still be seen. Increasing severity of parental myopia may lead to an increased risk of myopia in children. 
As shown in Table 5, comparable results have been reported previously. For instance, an epidemiological survey from China showed that children with a single parent with myopia were twice as likely to have myopia as their non-myopic counterparts, and those with both parents with myopia were three times as likely to have myopia as their non-myopic counterparts [28]. A study conducted by Ip et al. [23] identified the odds of childhood myopia at $2.3(95 \% \mathrm{Cl} 1.8-2.9)$ when one parent was myopic and $7.9(95 \% \mathrm{Cl} 5.0-$ 12.4) when both parents were myopic after adjusting for environmental and demographic factors, compared with children whose parents were not myopic. In another population-based cross-sectional study in Korea, the prevalence rate ratio (PRR) for children's myopia and high myopia with myopic parents were 1.34 (95\% Cl 1.24-1.45) and 3.11 (95\% Cl 1.93-5.01), respectively. The PRR of myopia and high myopia in children increased significantly to 1.37 (95\% Cl 1.04-1.81) and 11.41 (95\% Cl 6.24-20.88), as the degree of parental myopia increased $(p<0.001$, respectively). Children with two myopic parents were more myopic than those with only one myopic parent $(p<0.001$, respectively) [26]. An American study conducted on children aged $13.7 \pm 0.5$ years showed that among children in families with two parents with myopia, $32.9 \%$ had myopia compared with $18.2 \%$ of children in families in which only one parent was myopic and $6.3 \%$ of children in families with no parents with myopia [27]. 
Table 5

Association between parental myopia and refractive status of the offspring

\begin{tabular}{|c|c|c|c|c|c|c|}
\hline Sum & Author & Year & Country & $\begin{array}{l}\text { Sample } \\
\text { size }\end{array}$ & $\begin{array}{l}\text { Prevalence of } \\
\text { myopia (\%) }\end{array}$ & Result \\
\hline 1 & $\begin{array}{l}\text { Pärssinen } \\
\text { [48] }\end{array}$ & $\begin{array}{l}1983- \\
1984\end{array}$ & Finland & 240 & / & Yes \\
\hline 2 & Wu[49] & 2012 & China & 43,771 & 34.39(F) 29.4(M) & Yes \\
\hline 3 & Mutti[27] & $\begin{array}{l}1991- \\
1996\end{array}$ & USA & 366 & 18.3 & Yes \\
\hline 4 & Jones[50] & $\begin{array}{l}1989- \\
2001\end{array}$ & USA & 514 & 21.6 & Yes \\
\hline 5 & Zhang[51] & $\begin{array}{l}1950- \\
2013\end{array}$ & $\begin{array}{l}\text { Asia, Europe, USA, } \\
\text { Australia }\end{array}$ & 31,677 & 8,393 & Yes \\
\hline 6 & Zadnik[29] & $\begin{array}{l}1989- \\
2010\end{array}$ & USA & 4,512 & / & No \\
\hline 7 & $\operatorname{Lim}[26]$ & $\begin{array}{l}2008- \\
2012\end{array}$ & Korea & 3,862 & 2495(64.6) & Yes \\
\hline 8 & $\begin{array}{l}\text { Pärssinen } \\
\text { [52] }\end{array}$ & $\begin{array}{l}1983- \\
1984\end{array}$ & Finland & 240 & / & Yes \\
\hline 9 & Xiang[53] & 2000 & China & 1,567 & 57.7 & Yes \\
\hline 10 & Lee[54] & $\begin{array}{l}2010- \\
2011\end{array}$ & China & 5,187 & 86.1 & Yes \\
\hline 11 & Greene[55] & 2015 & USA & 165 & 38.5 & Yes \\
\hline 12 & Liao[56] & $\begin{array}{l}2006- \\
2017\end{array}$ & China (Guangzhou) & 1,831 & / & Yes \\
\hline 13 & Hsu[57] & $\begin{array}{l}2013- \\
2016\end{array}$ & China (Taiwan) & 11,590 & 36.4 & Yes \\
\hline 14 & Kurtz[58] & $\begin{array}{l}1997- \\
1998\end{array}$ & USA & 232 & / & Yes \\
\hline 15 & Ip[23] & $\begin{array}{l}2003- \\
2005\end{array}$ & Australia & 2,353 & / & Yes \\
\hline 16 & $\begin{array}{l}\text { Jones- } \\
\text { Jordan [59] }\end{array}$ & $\begin{array}{l}1989- \\
2010\end{array}$ & USA & 2,158 & / & Yes \\
\hline 17 & Lam[26] & $\begin{array}{l}1998- \\
2000\end{array}$ & China (Hong Kong) & 7,560 & / & Yes \\
\hline 18 & Edwards[30] & $\begin{array}{l}1991- \\
1996\end{array}$ & China (Hong Kong) & 123 & $53 \%$ & No \\
\hline
\end{tabular}


Although the above studies were conducted in different decades and regions, all showed that the myopia status of the children was related to parental myopia. The subjects of this study had a comparatively high prevalence of myopia and were relatively well educated.

However, two studies concluded that there was no association between parental myopia and the refractive status of the offspring $[29,30]$. There are several possible reasons for this discrepancy. First, we speculated that the subjects differed considerably between our study and those two prior studies in terms of age, ethnicity, academic pressure, and life-style. Second, the social status and educational level of parents potentially influence the association between their myopia status and that of their children. Finally, the discrepancy could be due to differences in the sensitivity and specificity of the statistical methods used.

The prevalence of myopia identified in this study was higher than those in previous reports. For example, a prevalence of $29.1 \%$ was reported in children of Chinese ethnicity in Singapore [32], $47.9 \%$ in Saudi Arabian college students [33], 30.6\% in adults across Europe [34], and $21.1 \%$ in north Indian schoolchildren [35]. However, the prevalence of myopia in this study was similar to those reported in male Taiwanese military members (86.1\%) [21], Chinese students aged $17-18$ years (74.2\%) [36], and teenaged high-school students in Singapore (73.9\%) [37]. The discrepancy may be due to differences in environmental factors and educational pressures between East Asian (especially Chinese) and Western students $[38,39]$. The educational pressure on East Asian students is greater than that on students in other countries [1]. We analyzed the prevalence of myopia in students from two universities in Shanghai, China. Due to the higher educational level of these students, they spent more time on near work in order to achieve good marks and get chance to study in university. This may explain their higher prevalence of myopia compared with the rates reported in other epidemiological studies [39-41].

This study found that age and ethnicity were closely associated with myopia $(p<0.001)$, which is largely in agreement with previous studies [25,34,42]. After adjusting for age and ethnicity, parental myopia was still an independent risk factor associated with the occurrence of myopia in the multivariate analysis. Our results thus suggest a familial predisposition for myopia.

This study has some limitations. First, compared with previous studies, this survey focused mainly on the relationship between myopia and heredity. However, in the myopia progression process, factors such as lifestyle, long-term and close distance learning and outdoor activities have not been ruled out, so our results may have been influenced by these factors. Second, data on parental myopia were self-reported by the participants. The self-reported measures of parental myopia may have overestimated the proportion of parents who wear spectacles to correct refractive problems other than myopia. Moreover, as our sample was limited to Chinese undergraduates, comparative studies should be undertaken of the hereditary differences in other nationalities to further explore myopia, which is a multifactorial disease. Finally, this study only investigated the relationship between parental refraction and that of their children; the additional measurement of the relationship between parental axial length and that of their offspring would enhance our understanding of the heritability of myopia. 
Previous studies identified an association between myopia and MMP-2, TIMP-2, TGF- $\beta$, miRNA-328, PAX6, miR-29a and miR-let-7i [43-47]. Using genetic data, an analysis of the correlation between parental genes and those of their children and refractive status would enable more accurate and efficient treatments for myopia, including molecular targeted therapies.

\section{Abbreviations}

\section{UCVA}

Uncorrected Visual Acuity

SER

Spherical Equivalent Refraction

SD

Standard Deviation

PRR

Prevalence Rate Ratio

\section{Declarations}

Ethics approval and consent to participate:

The Shanghai JiaoTong University School of Medicine Ethics Review Board and the Ethics Committee of Shanghai Ninth People's Hospital approved the study and the study was performed in accordance with the Declaration of Helsinki. All patients signed an informed consent form.

Consent for publication:

Not applicable.

Availability of data and materials:

The datasets for the analysis of the current study are readily available from the corresponding author on reasonable request.

Competing interests:

The authors declare that they have no competing interests.

Funding:

This work was supported by The Science and Technology Commission of Shanghai (17DZ2260100). The funders had no role in study design, data collection and analysis, decision to publish, or preparation of the manuscript.

Authors' contributions: 
WL, PX participated in the design of the study. WL, PX collected and analyzed the data. All authors interpreted the data. WL wrote the article. PX critically revised the article. CC and JZ reviewed the literature. All authors read and approved the final manuscript.

Acknowledgement:

Not applicable.

Other Acknowledgments:

The English in this document has been checked by at least two professional editors, both native speakers of English. For a certificate, please see:

http://www.textcheck.com/certificate/itKOWD

\section{References}

1. Morgan IG, French AN, Ashby RS, Guo X, Ding X, He M, Rose KA. The epidemics of myopia: Aetiology and prevention. Prog Retin Eye Res. 2018;62:134-49.

2. Wong HB, Machin D, Tan SB, Wong TY, Saw SM. Visual impairment and its impact on health-related quality of life in adolescents. Am J Ophthalmol. 2009;147(3):505-11 e501.

3. Wu PC, Huang HM, Yu HJ, Fang PC, Chen CT. Epidemiology of Myopia. Asia Pac J Ophthalmol (Phila). 2016;5(6):386-93.

4. Holden BA, Fricke TR, Wilson DA, Jong M, Naidoo KS, Sankaridurg P, Wong TY, Naduvilath TJ, Resnikoff S. Global Prevalence of Myopia and High Myopia and Temporal Trends from 2000 through 2050. Ophthalmology. 2016;123(5):1036-42.

5. He M, Zeng J, Liu Y, Xu J, Pokharel GP, Ellwein LB. Refractive error and visual impairment in urban children in southern china. Invest Ophthalmol Vis Sci. 2004;45(3):793-9.

6. Han SB, Jang J, Yang HK, Hwang JM, Park SK. Prevalence and risk factors of myopia in adult Korean population: Korea national health and nutrition examination survey 2013-2014 (KNHANES VI). PLoS One. 2019;14(1):e0211204.

7. Wu HM, Seet B, Yap EP, Saw SM, Lim TH, Chia KS. Does education explain ethnic differences in myopia prevalence? A population-based study of young adult males in Singapore. Optom Vis Sci. 2001;78(4):234-9.

8. Midelfart A, Kinge B, Midelfart S, Lydersen S. Prevalence of refractive errors in young and middleaged adults in Norway. Acta Ophthalmol Scand. 2002;80(5):501-5.

9. Cumberland PM, Bao Y, Hysi PG, Foster PJ, Hammond CJ, Rahi JS, Eyes UKB, Vision C. Frequency and Distribution of Refractive Error in Adult Life: Methodology and Findings of the UK Biobank Study. PLoS One. 2015;10(10):e0139780. 
10. Vitale S, Ellwein L, Cotch MF, Ferris FL 3rd, Sperduto R. Prevalence of refractive error in the United States, 1999-2004. Arch Ophthalmol. 2008;126(8):1111-9.

11. Murthy GV, Gupta SK, Ellwein LB, Munoz SR, Pokharel GP, Sanga L, Bachani D. Refractive error in children in an urban population in New Delhi. Invest Ophthalmol Vis Sci. 2002;43(3):623-31.

12. Neelam K, Cheung CM, Ohno-Matsui K, Lai TY, Wong TY. Choroidal neovascularization in pathological myopia. Prog Retin Eye Res. 2012;31(5):495-525.

13. Saw SM, Gazzard G, Shih-Yen EC, Chua WH. Myopia and associated pathological complications. Ophthalmic Physiol Opt. 2005;25(5):381-91.

14. Vongphanit J, Mitchell P, Wang JJ. Prevalence and progression of myopic retinopathy in an older population. Ophthalmology. 2002;109(4):704-11.

15. Wu L, Sun X, Zhou X, Weng C. Causes and 3-year-incidence of blindness in Jing-An District, Shanghai, China 2001-2009. BMC Ophthalmol. 2011;11:10.

16. Resnikoff S, Jonas JB, Friedman D, He M, Jong M, Nichols JJ, Ohno-Matsui K, Smith EL III, Wildsoet CF, Taylor HR, et al. Myopia - A 21st Century Public Health Issue. Invest Ophthalmol Vis Sci. 2019;60(3):Mi-ii.

17. Nickels S, Hopf S, Pfeiffer N, Schuster AK. Myopia is associated with education: Results from NHANES 1999-2008. PLoS One. 2019;14(1):e0211196.

18. Enthoven CA, Tideman JWL, Polling JR, Tedja MS, Raat H, Iglesias Al, Verhoeven VJM, Klaver CCW. Interaction between lifestyle and genetic susceptibility in myopia: the Generation R study. Eur J Epidemiol 2019.

19. Tedja MS, Haarman AEG, Meester-Smoor MA, Kaprio J, Mackey DA, Guggenheim JA, Hammond CJ, Verhoeven VJM, Klaver CCW, Consortium C. IMI - Myopia Genetics Report. Invest Ophthalmol Vis Sci. 2019;60(3):M89-105.

20. Schuster AK, Elflein HM, Pokora R, Urschitz MS. [Prevalence and Risk Factors of Myopia in Children and Adolescents in Germany - Results of the KiGGS Survey]. Klin Padiatr. 2017;229(4):234-40.

21. Lee YY, Lo CT, Sheu SJ, Lin JL. What factors are associated with myopia in young adults? A survey study in Taiwan Military Conscripts. Invest Ophthalmol Vis Sci. 2013;54(2):1026-33.

22. Wang L, Du M, Yi H, Duan S, Guo W, Qin P, Hao Z, Sun J. Prevalence of and Factors Associated with Myopia in Inner Mongolia Medical Students in China, a cross-sectional study. BMC Ophthalmol. 2017;17(1):52.

23. Ip JM, Huynh SC, Robaei D, Rose KA, Morgan IG, Smith W, Kifley A, Mitchell P. Ethnic differences in the impact of parental myopia: findings from a population-based study of 12-year-old Australian children. Invest Ophthalmol Vis Sci. 2007;48(6):2520-8.

24. Onal S, Toker E, Akingol Z, Arslan G, Ertan S, Turan C, Kaplan O. Refractive errors of medical students in Turkey: one year follow-up of refraction and biometry. Optom Vis Sci. 2007;84(3):175-80.

25. Rudnicka AR, Owen CG, Nightingale CM, Cook DG, Whincup PH. Ethnic differences in the prevalence of myopia and ocular biometry in 10- and 11-year-old children: the Child Heart and Health Study in 
England (CHASE). Invest Ophthalmol Vis Sci. 2010;51(12):6270-6.

26. Lim DH, Han J, Chung TY, Kang S, Yim HW, Epidemiologic Survey Committee of the Korean Ophthalmologic S. The high prevalence of myopia in Korean children with influence of parental refractive errors: The 2008-2012 Korean National Health and Nutrition Examination Survey. PLoS One. 2018;13(11):e0207690.

27. Mutti DO, Mitchell GL, Moeschberger ML, Jones LA, Zadnik K. Parental myopia, near work, school achievement, and children's refractive error. Invest Ophthalmol Vis Sci. 2002;43(12):3633-40.

28. Xiang F, He M, Morgan IG. The impact of parental myopia on myopia in Chinese children: populationbased evidence. Optom Vis Sci. 2012;89(10):1487-96.

29. Zadnik K, Sinnott LT, Cotter SA, Jones-Jordan LA, Kleinstein RN, Manny RE, Twelker JD, Mutti DO. Collaborative Longitudinal Evaluation of E, Refractive Error Study G: Prediction of Juvenile-Onset Myopia. JAMA Ophthalmol. 2015;133(6):683-9.

30. Edwards $\mathrm{MH}$. Effect of parental myopia on the development of myopia in Hong Kong Chinese. Ophthalmic Physiol Opt. 1998;18(6):477-83.

31. Sun J, Zhou J, Zhao P, Lian J, Zhu H, Zhou Y, Sun Y, Wang Y, Zhao L, Wei Y, et al. High prevalence of myopia and high myopia in 5060 Chinese university students in Shanghai. Invest Ophthalmol Vis Sci. 2012;53(12):7504-9.

32. Rose KA, Morgan IG, Smith W, Burlutsky G, Mitchell P, Saw SM. Myopia, lifestyle, and schooling in students of Chinese ethnicity in Singapore and Sydney. Arch Ophthalmol. 2008;126(4):527-30.

33. Alsaif BA, Aljindan MY, Alrammah HM, Almulla MO, Alshahrani SS. Refractive errors among Saudi college students and associated risk factors. Clin Ophthalmol. 2019;13:437-43.

34. Williams KM, Verhoeven VJ, Cumberland P, Bertelsen G, Wolfram C, Buitendijk GH, Hofman A, van Duijn CM, Vingerling JR, Kuijpers RW, et al. Prevalence of refractive error in Europe: the European Eye Epidemiology (E(3)) Consortium. Eur J Epidemiol. 2015;30(4):305-15.

35. Singh NK, James RM, Yadav A, Kumar R, Asthana S, Labani S. Prevalence of Myopia and Associated Risk Factors in Schoolchildren in North India. Optom Vis Sci. 2019;96(3):200-5.

36. You QS, Wu LJ, Duan JL, Luo YX, Liu LJ, Li X, Gao Q, Wang W, Xu L, Jonas JB, et al. Prevalence of myopia in school children in greater Beijing: the Beijing Childhood Eye Study. Acta Ophthalmol. 2014;92(5):e398-406.

37. Quek TP, Chua CG, Chong CS, Chong JH, Hey HW, Lee J, Lim YF, Saw SM. Prevalence of refractive errors in teenage high school students in Singapore. Ophthalmic Physiol Opt. 2004;24(1):47-55.

38. Tideman JWL, Polling JR, Hofman A, Jaddoe VW, Mackenbach JP, Klaver CC. Environmental factors explain socioeconomic prevalence differences in myopia in 6-year-old children. Br J Ophthalmol. 2018;102(2):243-7.

39. Low W, Dirani M, Gazzard G, Chan YH, Zhou HJ, Selvaraj P, Au Eong KG, Young TL, Mitchell P, Wong TY, et al. Family history, near work, outdoor activity, and myopia in Singapore Chinese preschool children. Br J Ophthalmol. 2010;94(8):1012-6. 
40. Teasdale TW, Goldschmidt E. Myopia and its relationship to education, intelligence and height. Preliminary results from an on-going study of Danish draftees. Acta Ophthalmol Suppl. 1988;185:41-3.

41. Williams SM, Sanderson GF, Share DL, Silva PA. Refractive error, IQ and reading ability: a longitudinal study from age seven to 11. Dev Med Child Neurol. 1988;30(6):735-42.

42. Guo L, Yang J, Mai J, Du X, Guo Y, Li P, Yue Y, Tang D, Lu C, Zhang WH. Prevalence and associated factors of myopia among primary and middle school-aged students: a school-based study in Guangzhou. Eye (Lond). 2016;30(6):796-804.

43. Gong B, Liu X, Zhang D, Wang P, Huang L, Lin Y, Lu F, Ma S, Cheng J, Chen R, et al. Evaluation of MMP2 as a candidate gene for high myopia. Mol Vis. 2013;19:121-7.

44. Liang CL, Hsi E, Chen KC, Pan YR, Wang YS, Juo SH. A functional polymorphism at 3'UTR of the PAX6 gene may confer risk for extreme myopia in the Chinese. Invest Ophthalmol Vis Sci. 2011;52(6):3500-5.

45. Chang CJ, Hsu CC, Chang CH, Tsai LL, Chang YC, Lu SW, Yu CH, Huang HS, Wang JJ, Tsai CH, et al. Let-7d functions as novel regulator of epithelial-mesenchymal transition and chemoresistant property in oral cancer. Oncol Rep. 2011;26(4):1003-10.

46. Tan J, Tong BD, Wu YJ, Xiong W. MicroRNA-29 mediates TGFbeta1-induced extracellular matrix synthesis by targeting wnt/beta-catenin pathway in human orbital fibroblasts. Int $\mathrm{J}$ Clin Exp Pathol. 2014;7(11):7571-7.

47. Chen KC, Hsi E, Hu CY, Chou WW, Liang CL, Juo SH. MicroRNA-328 may influence myopia development by mediating the PAX6 gene. Invest Ophthalmol Vis Sci. 2012;53(6):2732-9.

48. Parssinen $\mathrm{O}$, Kauppinen $\mathrm{M}$, Viljanen $\mathrm{A}$. The progression of myopia from its onset at age 8-12 to adulthood and the influence of heredity and external factors on myopic progression. A 23-year follow-up study. Acta Ophthalmol. 2014;92(8):730-9.

49. Wu X, Gao G, Jin J, Hua W, Tao L, Xu S, Tao F. Housing type and myopia: the mediating role of parental myopia. BMC Ophthalmol. 2016;16(1):151.

50. Jones LA, Sinnott LT, Mutti DO, Mitchell GL, Moeschberger ML, Zadnik K. Parental history of myopia, sports and outdoor activities, and future myopia. Invest Ophthalmol Vis Sci. 2007;48(8):3524-32.

51. Zhang X, Qu X, Zhou X. Association between parental myopia and the risk of myopia in a child. Exp Ther Med. 2015;9(6):2420-8.

52. Parssinen $\mathrm{O}$, Kauppinen $\mathrm{M}$. What is the influence of parents' myopia on their children's myopic progression? A 22-year follow-up study. Acta Ophthalmol. 2016;94(6):579-85.

53. Xiang F, He M, Morgan IG. The impact of severity of parental myopia on myopia in Chinese children. Optom Vis Sci. 2012;89(6):884-91.

54. Lee YY, Lo CT, Sheu SJ, Yin LT. Risk factors for and progression of myopia in young Taiwanese men. Ophthalmic Epidemiol. 2015;22(1):66-73. 
55. Greene PR, Medina A. Refraction data survey: 2nd generation correlation of myopia. Int Ophthalmol. 2016;36(5):609-14.

56. Liao C, Ding X, Han X, Jiang Y, Zhang J, Scheetz J, He M. Role of Parental Refractive Status in Myopia Progression: 12-Year Annual Observation From the Guangzhou Twin Eye Study. Invest Ophthalmol Vis Sci. 2019;60(10):3499-506.

57. Hsu CC, Huang N, Lin PY, Tsai DC, Tsai CY, Woung LC, Liu CJ. Prevalence and risk factors for myopia in second-grade primary school children in Taipei: A population-based study. J Chin Med Assoc. 2016;79(11):625-32.

58. Kurtz D, Hyman L, Gwiazda JE, Manny R, Dong LM, Wang Y, Scheiman M, Group C. Role of parental myopia in the progression of myopia and its interaction with treatment in COMET children. Invest Ophthalmol Vis Sci. 2007;48(2):562-70.

59. Jones-Jordan LA, Sinnott LT, Manny RE, Cotter SA, Kleinstein RN, Mutti DO, Twelker JD, Zadnik K. Collaborative Longitudinal Evaluation of E, Refractive Error Study G: Early childhood refractive error and parental history of myopia as predictors of myopia. Invest Ophthalmol Vis Sci. 2010;51(1):11521.

\section{Figures}

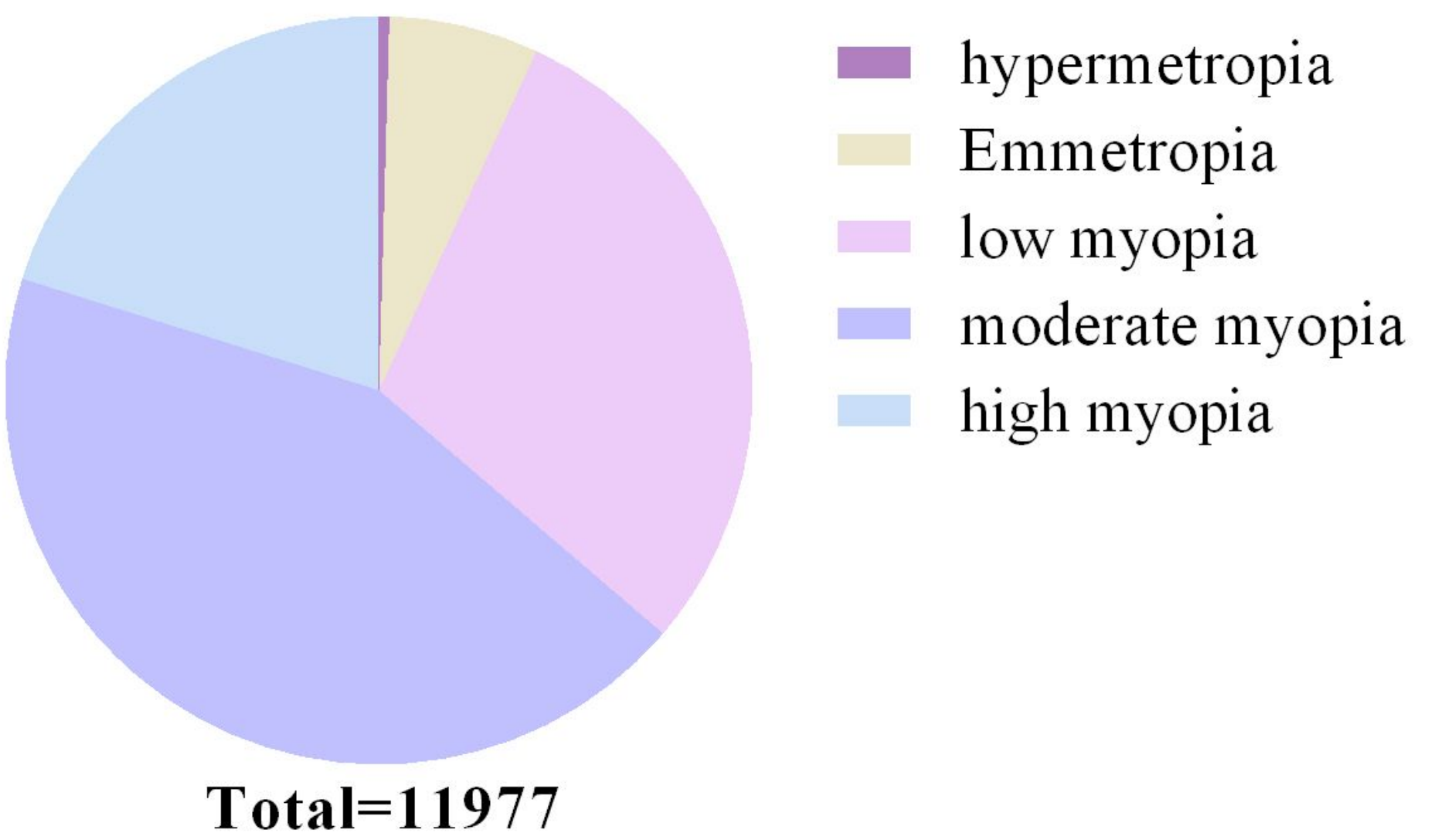

Figure 1 
Composition ratio of refractive state among 11,977 Chinese university students Hypermetropia: 54 (0.5\%); emmetropia: 777 (6.5\%); low myopia: 3511 (29.3\%); moderate myopia: 5218 (43.6\%); high myopia: 2517(20.2\%).
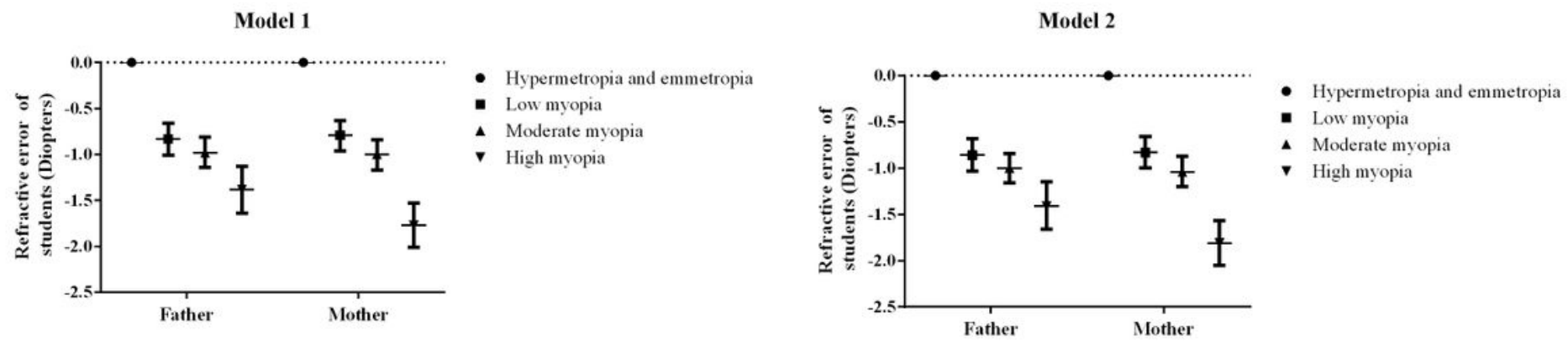

Figure 2

Generalized linear model analysis of parental myopia status and the refractive error (Diopters) among 11,977 Chinese university students X-Axes: Parental myopia status (Hypermetropia and emmetropia; low myopia; moderate myopia; high myopia). Y-Axes: Refractive error of students (Diopters).

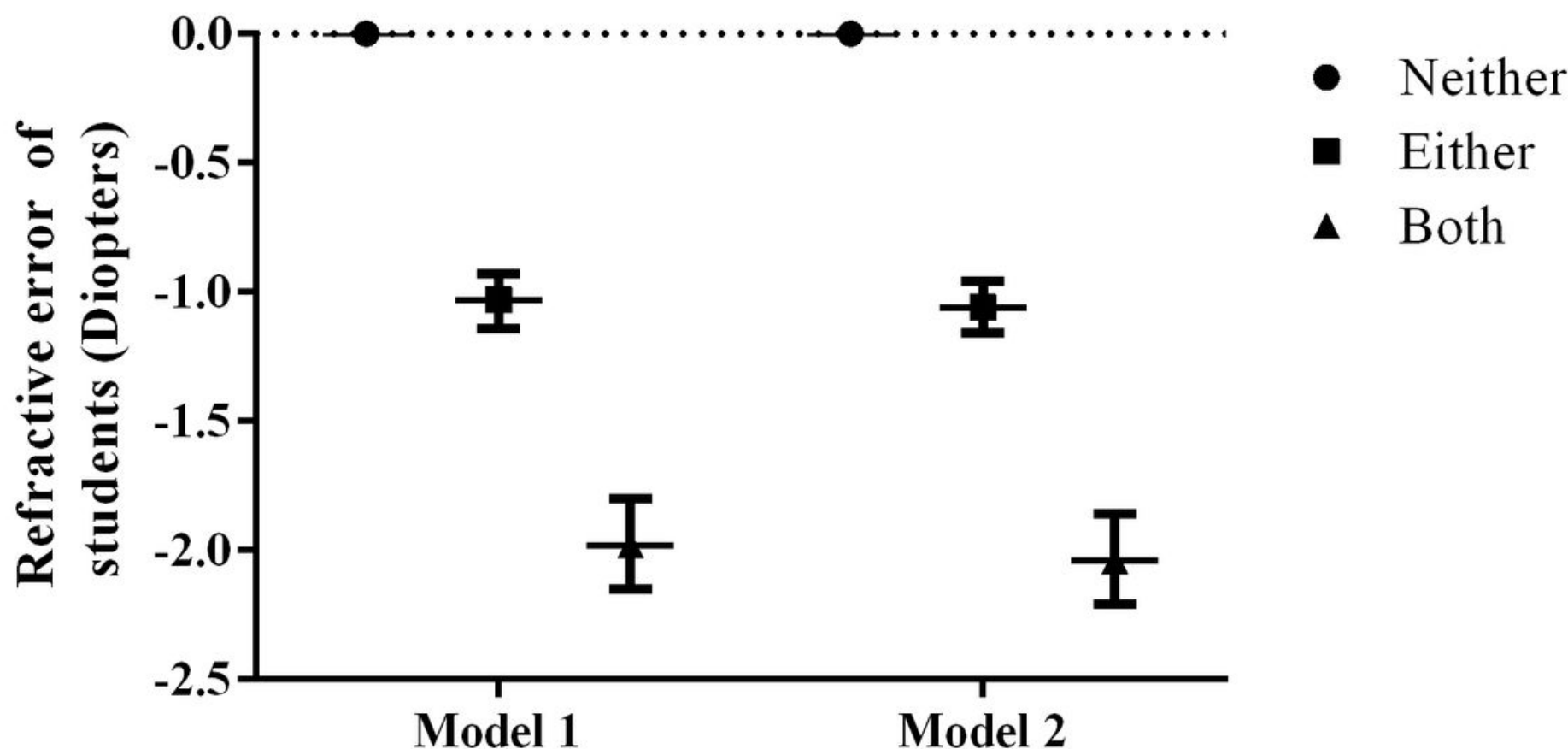

Parental myopia status

Figure 3

The association (mean difference $[95 \% \mathrm{Cl}]$ ) between the joint classification of parental myopia status and the refractive error (Diopters) among 11,977 college students X-Axes: Parental myopia status (neither myopic, either myopic, both myopic). Y-Axes: Refractive error of students (Diopters). 